\title{
Elastyczność polskich przedsiębiorstw
}

https://doi.org/10.33141/po.2005.11.02

Rafał Krupski

\section{Metoda badań}

$\mathbf{J}$ ednym z podstawowych problemów badawczych związanych z elastycznością przedsiębiorstw jest sprecyzowanie przedmiotu badań. Niestety, elastyczność nie jest kategorią jednoznacznie definiowaną, o czym można się przekonać studiując literaturę przedmiotu (np. [2, 3]). Można jednak ostatecznie ją jakoś zdefiniować i dalej badać to, co się samemu lub za wybraną propozycją literaturową przyjęło. Jednakże zwykle występują trudności z pomiarem tych kategorii, na których oparto te definicje (większość definicji elastyczności nawiązuje do czasu adaptacji, szybkości reakcji na zmiany przede wszystkim w otoczeniu). Innym podejściem jest przyjęcie jedynie domyślnej definicji elastyczności, dość szerokiej na tyle, że zmieściłoby się w niej wiele ujęć szczegółowych, ale nie operowanie nią explicite, a wyłącznie implicite, poprzez czynniki ją kształtujące. Tak postapili między innymi Duńczycy (Departament of Studies Aalborg University) badając elastyczność 1900 małych, średnich i dużych przedsiębiorstw [1]. Badania przeprowadzono na podstawie kwestionariusza ankiety składającego się z 27 zamkniętych pytań, dotyczących czterech zakresów tematycznych: • wykorzystywanie i zmiana zasad zarządzania i organizacji pracy, - zmiany w treści pracy i zapotrzebowania na kwalifikacje pracowników, - innowacje produktowe, procesowe, rynkowe, $\bullet$ zmiany dotyczące stopnia kooperacji ze stakeholders i intensywności konkurencji.

Konstrukcję wskaźnika elastyczności (ogólnej, sumarycznej całego przedsiębiorstwa) oparto na wynikach odpowiedzi na 14 pytań, które dotyczyły następujących obszarów:

- tygodniowe planowanie pracy,

- kontrolowanie pracy,

- funkcjonowanie wielozawodowych zespołów (interaktywnych),

- funkcjonowanie kól jakości,

- delegowanie uprawnien,

- integrowanie funkcji (np. produkcja/usługi - sprzedaż - finanse),

- przemieszczanie pracowników między różnymi obszarami funkcjonalnymi,

- ciagge szkolenie pracowników dostosowane do bieżących potrzeb,

- ogólna aktywność edukacyjna pracowników,

- długookresowe planowanie szkoleń,

- wprowadzanie istotnych innowacji produktowych niezależnie od bieżących usprawnień,

- wykorzystywanie nowych produktów w celu wejścia na nowe rynki,
Przegląd Organizacji, Nr 11 (790), 2005, ss. 10-11 www.przegladorganizacji.pl Towarzystwo Naukowe Organizacji i Kierownictwa (TNOiK)
- wykorzystywanie technologii IT,

- wykorzystywanie innych nowych technologii.

Wskaźnik elastyczności przyjmuje wartości całkowite z przedziału 0-14, przy czym „0” oznacza, że na żadne z 14 pytań nie uzyskano pozytywnej odpowiedzi. W tym przypadku oznacza to firmę całkowicie nieelastyczną. Wskaźnik równy 14 oznacza firmę maksymalnie elastyczną.

W badaniach wykazano między innymi, że firmy duże i średnie są bardziej elastyczne, podobnie firmy produkcyjne w porównaniu z firmami nieprodukcyjnymi. Ten zaskakujacy wynik wydał mi się konsekwencją wytypowanych obszarów badawczych, które być może dobrze opisują elastyczność tylko dużych firm, ale nie nadają się jednak do badania elastyczności małych firm. We własnych badaniach postanowiłem to sprawdzić.

Badania przeprowadziłem w grupie 201 przedsiębiorstw różnej wielkości i różnych branż za pośrednictwem studentów magisterskich studiów uzupełniających oraz studentów studiów podyplomowych. Wszyscy studenci otrzymali do wypełnienia tabelę zbudowana zgodnie z metodyką wielowymiarowej analizy porównawczej. Wszyscy oceniali elastyczność swoich firm według takich samych, ośmiu kryteriów, tzn.:

- innowacje produktowe,

- współpraca i partnerstwo,

- internacjonalizacja i dywersyfikacja działalności,

- decentralizacja decyzji/ szybkość decyzji,

- obserwacja klientów i konkurentów,

- próby pozyskania nowych klientów, próby wejścia na nowe rynki,

- szkolenia, ogólna aktywność edukacyjna pracowników,

- dostęp do własnych lub obcych środków finansowych i innych,

z założeniem, że im wyższa ocena z powyższych punktów widzenia, tym wyższa powinna być (jest?) elastyczność przedsiębiorstwa. Ankietowani sami lub w konsultacji z kierownictwami firm, nadawali wagi (rangi) powyższym kryteriom z dokładnością do 0,05, przyjmując jednocześnie, że ich suma wynosi równo 1 . Oceny z punktu widzenia każdego kryterium oddzielnie dokonywano według umownej skali dziesięciopunktowej, przy czym „1" oznaczało ocenę najgorsza, a „10” ocenę najlepszą. Współczynnik elastyczności We dla każdego z przedsiębiorstw obliczano jako średnioważoną ocenę (suma iloczynów wag poszczególnych kryteriów i ustalonych według nich jednostkowych ocen). Otrzymano 180 poprawnie wypełnionych tabel (ankiet). Współczynnik elastyczności We zawiera się w przedziale 1-10 i im jest większy, tym globalna oce- 
Tab. Globalna ocena elastyczności przedsiębiorstw

\begin{tabular}{|c|c|c|c|c|}
\hline \multirow[b]{2}{*}{ Wielkość firmy } & \multicolumn{3}{|c|}{ Ocena elastyczności } & \multirow[b]{2}{*}{$\Sigma$} \\
\hline & $\begin{array}{c}\text { niska } \\
\text { We } \leqslant 4\end{array}$ & $\begin{array}{c}\text { średnia } \\
7>\text { We }>4\end{array}$ & $\begin{array}{l}\text { wysoka } \\
\text { We } \geqslant 7\end{array}$ & \\
\hline $\begin{array}{c}\text { Mikro } \\
\mathbf{Z} \leqslant \mathbf{9}\end{array}$ & 0 & 25 & 10 & 35 \\
\hline $\begin{array}{c}\text { Małe } \\
49 \geqslant Z>9\end{array}$ & 6 & 20 & 28 & 54 \\
\hline $\begin{array}{c}\text { Średnie } \\
250 \geqslant Z>49\end{array}$ & 9 & 21 & 22 & 52 \\
\hline $\begin{array}{c}\text { Duże } \\
\mathrm{Z}>\mathbf{2 5 0}\end{array}$ & 0 & 25 & 14 & 39 \\
\hline$\Sigma$ & 15 & 91 & 74 & 180 \\
\hline
\end{tabular}

Źródło: badania własne.

na elastyczności przedsiębiorstwa jest wyższa. W tabeli zaprezentowano wyniki badań tak rozumianej elastyczności. Badane przedsiębiorstwa podzielono na: mikro, małe, średnie i duże firmy w zależności od liczby zatrudnionych ( $\mathbf{Z}$ w tabeli). Drugim kryterium ich podziału jest wskaźnik elastyczności globalnej We. Jako mało elastyczne uznano firmy, dla których wskaźnik ten kształtuje sie na poziomie 4 i poniżej. Za przedsiębiorstwa średnio elastyczne przyjęto te, dla których wskaźnik We kształtuje się pomiędzy 4 a 7. Firmy o wysokiej elastyczności mają wskaźnik We powyżej 7.

\section{Wyniki badań elastyczności przedsiębiorstw}

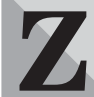
badań wynika, że $51 \%$ przedsiębiorstw można uznać za średnio elastyczne, a $41 \%$ to firmy bardzo elastyczne. Największą elastycznościa charakteryzuja się przede wszystkim małe i średnie firmy, choć jednocześnie w tej grupie przedsiębiorstw jest najwięcej firm nieelastycznych. W grupie dużych firm zarejestrowano wyłącznie albo średnią elastyczność (w 64\%), albo dużą (w $36 \%$ populacji dużych przedsiębiorstw).

Oprócz globalnej oceny elastyczności, na podstawie wypełnionych ankiet (tabela) można również wyciagnać wnioski o wpływie poszczególnych czynników elastyczności na wartość wskaźnika We. Analiza materiału empirycznego w tym zakresie (nie prezentowanego w artykule) doprowadziła do następujących wniosków.

W grupie mikroprzedsiębiorstw ogólną elastyczność obniża przede wszystkim:

- niski stopień internacjonalizacji i dywersyfikacji działalności oraz

- utrudniony dostęp do własnych lub obcych środków finansowych i innych.

Najwięcej wskazań czynników decydujących o względnie wysokiej elastyczności w tej grupie przedsiębiorstw dotyczyło:

- prób pozyskiwania nowych klientów, prób wejścia na nowe rynki,

- współpracy i partnerstwa oraz

- szybkości podejmowanych decyzji.

W grupie małych przedsiębiorstw w większości przypadków uznano, że ogólną elastyczność obniżają przede wszystkim:
- niedostateczne szkolenia i niedostateczna ogólna aktywność edukacyjna pracowników,

- niedostateczny stopień internacjonalizacji oraz dywersyfikacji działalności,

- dostęp do własnych i obcych środków finansowych $\mathrm{i}$ innych.

Czynnikami pozytywnie wpływajacymi na elastyczność działania w tej grupie firm są:

- próby pozyskiwania nowych klientów, nowych rynków zbytu,

- szybkość decyzji oraz

- innowacje produktowe.

W grupie średnich przedsiębiorstw elastyczność obniżają:

- dostęp do własnych i obcych środków finansowych i innych

- szybkość decyzji oraz

- obserwacje klientów i konkurentów (niedostateczny monitoring)

To, co pozytywnie kształtuje elastyczność w tej grupie firm, to przede wszystkim:

- innowacje produktowe oraz

- próby pozyskiwania nowych klientów, próby wejścia na nowe rynki

W grupie dużych przedsiębiorstw najwięcej wskazań czynników obniżających globalną elastyczność dotyczyło:

- szybkości podejmowanych decyzji oraz

- dostępu do własnych lub obcych środków finansowych i innych.

Główne czynniki pozytywnie kształtujące tę elastyczność to:

- próby pozyskiwania nowych klientów, próby wejścia na nowe rynki oraz

- współpraca i partnerstwo.

\section{Podsumowanie}

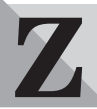

przeprowadzonych badań nie wynika jednoznacznie, że przedsiębiorstwa mniejsze sa bardziej elastyczne od dużych, jak to wynika z obiegowych opinii lub że jest odwrotnie, jak to wynika $\mathrm{z}$ badań duńskich. $\mathrm{Z}$ tych badań wynika natomiast, że w przypadku małych i średnich firm istnieja skrajne przypadki zarówno dużej, jak i małej elastyczności. W przypadku dużych firm natomiast przypadki małej elastyczności w praktyce nie występuja.

Wśród czynników zmniejszających elastyczność firm jest jeden niezależny od wielkości przedsiębiorstw. Jest nim ograniczony dostęp do własnych lub obcych środków (w tym finansowych).

prof. dr hab. Rafat Krupski

BIBLIOGRAFIA

Akademia Ekonomiczna we Wrocławiu

[1] LUND R., GJERDING A.N., The Flexible Company. Innovation, Work Organization and Human Resource Management, międzynarodowa konferencja OECD i Human Resource Development, Canada, Ottawa, 2-3 grudzień 1996: Changing Workplace Strategies: Achieving Better Outcomes for Enterprises, Workers and Society.

[2] OSBERT-POCIECHA G., Elastyczność przedsiebiorstwa - jej atrybuty i wymiary w literaturze przedmiotu, [w:] Nowe kierunki $w$ zarzadzaniu przedsiębiorstwem - między teoria $i$ praktyka, red. H. JAGODA i J. LICHTARSKI, Wyd. AE Wrocław, nr 1014, s. 73-81.

[3] Zarzadzanie przedsiębiorstwem $w$ turbulentnym otoczeniu. Ku superelastycznej organizacji, red. R. KRUPSKI, PWE, Warszawa 2005. 